\title{
PENERAPAN MODEL PEMBELAJARAN KOOPERATIF TIPE TALKING STICK BERBANTUAN DADU DAN MICROSOFT POWERPOINT
}

\author{
Maria Eustachia Stefani Kewa Koten ${ }^{1}$, Sri Hariyani ${ }^{2}$, Vivi Suwanti ${ }^{3}$ \\ Prodi Pendidikan Matematika, Universitas Kanjuruhan Malang ${ }^{1,2,3}$ \\ eustachiakoten@gmail.com, srihariyani@unikama.ac.id,vivi_devbatghost@unikama.ac.id
}

\begin{abstract}
Abstrak. Penelitian ini bertujuan untuk mendeskripsikan penerapan model pembelajaran kooperatif tipe talking stick berbantuan dadu dan microsoft power point untuk meningkatkan hasil belajar peserta didik kelas VIII B SMP PGRI 6 Malang. Jenis penelitian ini adalah Penelitian Tindakan Kelas dengan menggunakan pendekatan kualitatif. Teknik pengumpulan data dilakukan dengan observasi, tes, wawancara dan dokumentasi. Langkah-langkah pembelajaran meliputi: (1) Guru menjelaskan materi dan menampilkan contoh soal melalui power point, (2) Guru membagi peserta didik ke dalam 6 kelompok yang beranggotakan 5 orang dan dua kelompok lainnya beranggotakan 6 orang, (3) Guru menyiapkan tongkat, dadu dan nomor yang digunakan peserta didik, (4) Guru membagikan nomor kepada setiap peserta didik dalam kelompok, (5) Guru menjelaskan aturan model talking stick berbantuan dadu dan microsoft power point, (6) Guru memainkan musik, peserta didik mengoper tongkat, (7) Guru melempar dadu dan menampilkan soal di power point, (8) Peserta didik mengerjakan soal, (8) Guru memberikan penghargaan kepada kelompok yang memperoleh skor tertinggi, dan (9) Guru bersama peserta didik menyimpulkan materi yang dipelajari. Hasil penelitian menunjukkan persentase ketuntasan hasil belajar peserta didik meningkat dari 56,25\% pada Pra tindakan menjadi $65,62 \%$ pada siklus I dan $81,25 \%$ pada siklus II.
\end{abstract}

Kata Kunci: pembelajaran kooperatif, talking stick, dadu, power point

\section{PENDAHULUAN}

Matematika merupakan mata pelajaran yang diterapkan di setiap jenjang pendidikan (Crismono, 2017). Matematika sebagai salah satu mata pelajaran di sekolah merupakan mata pelajaran yang dapat membantu peserta didik memahami pengetahuan melalui proses (Afifah, 2012). Hal ini dikarenakan karakteristik matematika yang abstrak sehingga memerlukan konsentrasi dan keseriusan yang tinggi untuk memahaminya (Mustamid, 2015). Oleh karena itu, pada pembelajaran matematika diharapkan guru dapat menjelaskan materi dengan cara yang menarik agar peserta didik tertarik untuk belajar matematika. Salah satu cara agar peserta didik dapat tertarik adalah dengan menerapkan metode pembelajaran yang menyenangkan.

Berdasarkan pengamatan pada proses pembelajaran di SMP PGRI 6 Malang, terlihat bahwa peserta didik hanya cenderung mengandalkan penjelasan dari guru. Peserta didik tidak mau mencoba hal-hal baru karena peserta didik malas mengikuti pelajaran matematika, beberapa diantaranya cenderung pasif dan pendiam karena takut untuk bertanya. Saat pembelajaran matematika berlangsung peserta didik cenderung ramai dan asyik sendiri, sehingga tidak mendengarkan penjelasan yang disampaikan oleh guru. Berdasarkan hasil wawancara, guru mata pelajaran menyampaikan bahwa guru belum pernah menggunakan metode pembelajaran talking stick. Hasil ujian tengah semester (UTS) juga menunjukkan bahwa persentase ketuntasan hasil belajar peserta didik sebesar 56,25\%, dengan 18 peserta didik masih memperoleh nilai di bawah KKM.

Berkaitan dengan permasalahan yang ditemukan oleh peneliti di atas maka solusi yang diberikan untuk meningkatkan hasil belajar peserta didik adalah dengan menerapkan model pembelajaran yang efektif. Model pembelajaran yang dimaksudkan adalah model pembelajaran yang mampu membuat peserta didik lebih aktif dalam proses pembelajaran tanpa mengabaikan 
aspek waktu, kesenangan, kebebasan, dan ketiadaan tekanan terhadap peserta didik (Kurniati, 2017). Salah satu model pembelajaran yang memungkinkan keadaan tersebut adalah pembelajaran kooperatif. Melalui penggunaan model pembelajaran ini, diharapkan proses pembelajaran di kelas dapat memotivasi peserta didik untuk terlibat aktif dalam pembelajaran, bukan sekedar guru yang menjadi pusat pembelajaran. Pembelajaran kooperatif adalah pembelajaran yang memberikan kesempatan yang sama pada setiap anggota kelompok untuk berinteraksi antara satu sama lain mengenai pelajaran dan mendorong mereka untuk mengkomunikasikan ide dalam suasana yang nyaman (Sutrisno dkk, 2015). Pembelajaran kooperatif merupakan model pembelajaran dimana peserta didik dibagi kedalam kelompokkelompok kecil dengan kemampuan berbeda-beda, sehingga peserta didik diharapkan bisa saling bekerja sama (Hanisah, 2014). Model pembelajaran kooperatif yang dapat membantu meningkatkan hasil belajar peserta didik adalah talking stick.

Model talking stick merupakan model pembelajaran yang membagi peserta didik ke dalam kelompok dan diterapkan dengan menggunakan tongkat (Novida, 2016). Model pembelajaran talking stick merupakan model yang dapat diterapkan di segala jenjang pendidikan termasuk SMP. Model ini membuat peserta didik dapat bekerja sendiri dan memberikan waktu kepada peserta didik untuk berpartisipasi secara optimal (Putri dkk, 2017). Model talking stick mengurangi terjadinya monopoli oleh peserta didik yang mampu, dan dapat memberikan kesempatan kepada peserta didik yang kurang mampu untuk mengemukakan pendapat (Puspitawangi dkk, 2016).

Pembelajaran dengan menggunakan model pembelajaran kooperatif tipe talking stick telah dilakukan Minu (2018). Penelitian menunjukkan persentase klasikal setelah menggunakan model pembelajaran talking stick adalah $44,70 \%$ pada siklus I dan $71,10 \%$ pada siklus II. Malisa (2014) melaporkan bahwa hasil belajar peserta didik dengan menggunakan model pembelajaran talking stick memperoleh persentase klasikal yang meningkat menjadi $67,78 \%$ dari presentasi klasikal pra tindakan yakni $28,17 \%$. Peningkatan hasil belajar sebelum dan setelah diajar dengan model talking stick adalah sebesar 39,61\%.

Berbeda dengan penelitian sebelumnya yang tanpa menggunakan media, pada penerapan model talking stick yang dilakukan pada penelitian ini menggunakan bantuan dadu dan media power point. Susiliana dkk (2009:102) menyatakan bahwa program Microsoft Office Power Point adalah salah satu software yang dirancang khusus untuk menampilkan program multimedia dengan menarik, mudah dalam pembuatan, mudah dalam penggunaan dan relatif murah, karena tidak membutuhkan bahan baku selain alat untuk menyimpan data (data storage). Kusuma (2013:2) mengatakan bahwa media pembelajaran memiliki beberapa manfaat, diantaranya menghilangkan stres, mengajak peserta didik terlibat penuh dalam pembelajaran, dan membangun kegiatan belajar yang menyenangkan. Media power point pada penelitian ini digunakan untuk membantu peserta didik dalam memahami materi dan memudahkan peserta didik untuk mengingat materi karena ditampilkan dengan cara yang menarik. Selain itu, diharapkan agar selama pembelajaran terutama dalam penyampaian materi, peserta didik bisa fokus pada penjelasan karena materi disampaikan secara ringkas dan jelas menggunakan power point. Media berupa power point dapat disajikan dengan beberapa cara yakni menggunakan gambar, fitur suara, dan video yang disenangi oleh peserta didik. Pada penelitian ini, peneliti juga menggunakan dadu untuk membantu pembelajaran. Dadu digunakan sebagai permainan yakni peserta didik yang mengerjakan soal dan nomor soal yang akan dikerjakan diundi menggunakan dadu.

Penelitian ini penting dilakukan karena kondisi kelas yang diteliti membutuhkan pembaruan dalam hal proses pembelajaran. Pembelajaran yang selama ini dilakukan adalah model pembelajaran yang konvensional. Sehingga peneliti memutuskan untuk melakukan penelitian dengan menerapkan model pembelajaran yang membantu peserta didik untuk aktif dan membuat suasana kelas lebih menyenangkan.

Hasil penelitian diharapkan dapat memberikan manfaat antara lain adalah: (1) sebagai bahan referensi yang bisa digunakan oleh peneliti yang lain sebagai informasi dan (2) masukan bagi guru sebagai metode alternatif untuk memperbaiki dan meningkatkan pembelajaran agar pembelajaran tidak hanya terpaku dengan metode ceramah dan pemberian tugas. 


\section{METODE PENELITIAN}

Pendekatan yang digunakan dalam penelitian ini adalah pendekatan kualitatif, karena kondisi yang diteliti memenuhi beberapa karateristik penelitian kualitatif yakni peneliti sebagai instrumen utama dan juga terlibat langsung dalam penelitian. Data yang dikumpulkan sebagian besar berupa kata-kata atau kalimat dan data yang berupa angka diolah dan dianalisis sehingga dapat dideskripsikan.

Penelitian ini merupakan Penelitian Tindakan Kelas (PTK) karena penelitian ini terjadi di dalam kelas dan bersiklus untuk meningkatkan hasil pembelajaran di kelas. Tindakan pada penelitian ini berupa penerapan langkah-langkah model pembelajaran Talking Stick berbantuan Dadu dan Microsoft Power Point yang dapat meningkatan hasil belajar peserta didik kelas VIIIB SMP PGRI 6 Malang. Penelitian ini dilakukan secara bersiklus. Apabila pada siklus pertama yang dijalankan belum mencapai keberhasilan maka peneliti melanjutkan pada siklus berikutnya.

Sesuai dengan jenis penelitian yang telah dikemukakan di atas, maka kehadiran peneliti di lapangan mutlak karena peneliti berperan secara keseluruhan dalam proses penelitian. Peneliti disini bertindak sebagai perencana, pelaksana dalam pembelajaran, pengumpul data, penganalisis, dan pelapor hasil penelitian. Dengan kata lain, pada penelitian ini peneliti bertindak sebagai instrumen utama. Pengumpulan data selama proses pelaksanaan tindakan dibantu oleh guru mata pelajaran matematika dan teman sejawat.

Sumber data dalam penelitian ini adalah peserta didik kelas VIII B SMP PGRI 6 Malang semester ganjil tahun pelajaran 2019/2020 yang berjumlah 32 peserta didik, yang terdiri dari 14 peserta didik perempuan dan 18 peserta didik laki-laki. Data yang akan dikumpulkan dalam penelitian ini meliputi: (1) Hasil tes yang diberikan pada setiap akhir tindakan, (2) Hasil observasi selama proses pembelajaran yang digunakan untuk mengukur aktivitas guru dan aktivitas peserta didik selama proses pembelajaran, (3) Wawancara yang dilakukan terhadap peserta didik yang berkaitan dengan pembelajaran yang telah dilakukan, dan (4) Dokumentasi yang dilakukan selama proses pembelajaran berlangsung.

Metode pengumpulan data merupakan langkah paling utama dalam penelitian karena bertujuan untuk mendapatkan data. Dalam penelitian ini, pengumpulan data dilakukan dengan cara: (1) Tes akhir siklus yang digunakan untuk mengetahui hasil belajar peserta didik setelah menggunakan model pembelajaran kooperatif tipe talking stick berbantuan dadu dan microsoft power point pada materi sistem persamaan linear dua variabel. Tes yang digunakan adalah tes uraian, skor tes peserta didik diperoleh dari hasil tes pada akhir pembelajaran. Soal tes berjumlah 3 soal dengan indikator pengetahuan, pemahaman dan penerapan. (2) Observasi yang diamati yaitu aktivitas guru dan peserta didik selama proses pembelajaran menggunakan model talking stick berbantuan dadu dan microsoft powerpoint. Kegiatan observasi bertujuan untuk mengetahui kesesuaian antara pelaksanaan tindakan dengan perencanaan yang telah dibuat sebelumnya. Kegiatan yang diamati berupa aktivitas guru dan aktivitas peserta didik selama pembelajaran. Lembar observasi keterlaksanaan pembelajaran diisi oleh guru mata pelajaran matematika SMP PGRI 6 Malang dan teman sejawat. (3) Wawancara yang dilakukan di akhir siklus I bertujuan untuk mengetahui tanggapan peserta didik setelah melaksanakan pembelajaran talking stick berbantuan dadu dan microsoft power point, dan (4) Dokumentasi data-data yang mendukung penelitian meliputi nama peserta didik kelas VIII B yang akan menjadi subjek dalam penelitian, dokumentasi seluruh kegiatan peserta didik selama pembelajaran berlangsung, dan hasil observasi aktivitas guru dan peserta didik.

Data yang terkumpul dalam penelitian ini dianalisis menggunakan metode analisis data kualitatif. Analisis data terdiri dari tiga alur kegiatan yang terjadi secara bersamaan yaitu: (1) Reduksi data pada penelitian ini merupakan proses memilih, memfokuskan, dan menyederhanakan data yang diperoleh. Data yang diperoleh pada penelitian ini yaitu, hasil tes peserta didik, hasil observasi aktivitas guru, hasil observasi aktivitas peserta didik dan hasil wawancara. Data ini kemudian dipilih dan diklarifikasikan untuk mendapatkan data yang dibutuhkan. (2) Penyajian data merupakan kegiatan menyajikan sekumpulan informasi yang tersusun untuk memberikan kemungkinan adanya penarikan kesimpulan dan pengambilan tindakan. Penyajian data pada penelitian ini berupa tabel. Data yang akan dikumpulkan adalah dua jenis data, yaitu data kualitatif berupa wawancara serta observasi guru dan peserta didik 
yang disajikan secara deskriptif. Data kuantitatif berupa skor tes hasil belajar peserta didik dan skor hasil observasi guru dan peserta didik.

Perhitungan persentase peserta didik yang tuntas belajar adalah sebagai berikut:

Keterangan:

persentase peserta didik tuntas

banyaknya peserta didik yang memenuhi KKM

banyaknya seluruh peserta didik satu kelas.

Berdasarkan Kriteria Ketuntasan Minimal (KKM) pada SMP PGRI 6 Malang, peserta didik dikatakan tuntas apabila memperoleh skor sekurang-kurangnya 75.

Observasi penelitian terdiri dari dua yaitu observasi terhadap guru dan observasi terhadap peserta didik. Data lembar observasi guru dan peserta didik dianalisis dengan menggunakan persentase skor perolehan. Skor yang diperoleh masing-masing indikator dijumlahkan dan hasilnya disebut jumlah skor. Selanjutnya dihitung persentase nilai rataratanya dengan kriteria penilaian sebagai berikut:

Skor maksimal hasil observasi guru adalah 100 dan skor maksimal hasil observasi peserta didik adalah sebesar 92. Setelah melakukan perhitungan, peneliti akan mengkategorikan tingkat hasil observasi yang diperoleh. Pengkategorian dilakukan sesuai dengan pendapat Sudjana (2009) yaitu:

Tabel 1. Kategori hasil observasi

\begin{tabular}{cc}
\hline Interval & Kategori \\
\hline & Sangat Baik \\
Baik \\
Cukup Baik \\
Kurang Baik \\
& Tidak Baik \\
\hline
\end{tabular}

Penarikan kesimpulan dilakukan untuk melihat penafsiran dan evaluasi keberhasilan pelaksanaan penelitian. Hasil penafsiran dan evaluasi antara lain adalah perbedaan antara rancangan dan pelaksanaan tindakan, perlunya perubahan tindakan, alternatif tindakan yang dianggap tepat dan kendala yang dihadapi. Penelitian ini dikatakan berhasil apabila: (1) Berdasarkan hasil tes akhir siklus, minimal 70\% peserta didik mencapai kriteria tuntas dan (2) Hasil observasi guru maupun peserta didik mencapai kriteria minimal baik.

Pengecekan keabsahan data dilakukan untuk menghindari kesalahan dan kekeliruan data yang terkumpul. Pengecekan keabsahan data didasarkan pada kriteria derajat kepercayaan antara lain, (1) Ketekunan pengamat berarti penulis melakukan pengamatan terhadap jalannya proses pembelajaran dengan teliti dan tekun serta berkesinambungan. Selain itu, peneliti juga menguraikan secara rinci jalannya proses perolehan data dari hasil penelitian. (2) Triangulasi yang digunakan pada penelitian ini adalah triangulasi sumber dan triangulasi teknik. Triangulasi sumber yaitu peneliti mengumpulkan data dengan teknik yang sama kepada sumber yang berbeda. Pada penelitian ini peneliti memberikan tes tulis dengan soal yang sama kepada 32 peserta didik dan peneliti melakukan wawancara dengan pedoman wawancara yang sama terhadap 3 peserta didik. Triangluasi teknik berarti peneliti mengumpulkan data dengan teknik yang berbeda dari sumber data yang sama. Triangulasi teknik yang dilakukan dalam penelitian ini yaitu membandingkan dan memeriksa kembali hasil pengamatan dan rekaman video kegiatan pelaksanaan tindakan di kelas untuk mengetahui kebenaran data. (3) Pengecekan sejawat dilakukan dengan cara mengekspose hasil sementara atau hasil akhir yang diperoleh dalam bentuk diskusi dengan rekan sejawat. Hal ini dilakukan dengan harapan peneliti mendapat masukan atau saran mengenai konteks penelitian sehingga data yang diperoleh benar- 
benar mencerminkan data yang akurat dan dapat dipertanggung jawabkan. Pemeriksaan teman sejawat juga dimaksudkan untuk mendapatkan saran atau masukan yang berguna bagi penelitian ini. Selain teman sejawat, peneliti juga melakukan diskusi dengan guru matematika kelas VIII B SMP PGRI 6 Malang untuk membahas tentang proses dan hasil yang diperoleh selama proses pembelajaran. Diskusi dilakukan pada setiap akhir pembelajaran di setiap siklus untuk menentukan pemberian tindakan berikutnya. Apabila tindakan pada siklus awal tidak tuntas atau tidak berhasil, peneliti memperbaiki tindakan pada siklus selanjutnya.

\section{HASIL DAN PEMBAHASAN}

Data awal sebelum diterapkannya tindakan menunjukkan bahwa persentase ketuntasan belajar peserta didik pada ujian tengah semester (UTS) adalah sebesar 56,25\% dengan jumlah peserta didik yang tidak tuntas atau tidak memenuhi KKM adalah sebanyak 18 peserta didik. Berdasarkan hasil tes pada tindakan siklus I yang dilakukan, dapat diketahui bahwa dari 32 peserta didik terdapat 21 peserta didik tuntas dalam belajar dengan nilai $\geq 75$ dan 11 peserta didik dinyatakan tidak tuntas belajar karena memperoleh nilai di bawah KKM. Dengan demikian dapat dihitung persentase ketuntasan hasil belajar peserta didik secara klasikal adalah 65,62\%. Dari persentase tersebut, dapat diketahui bahwa persentase ketuntasan belajar masih berada di bawah standar ketuntasan belajar (standar ketuntasan belajar adalah 70\%).

Observasi kegiatan guru pada tindakan siklus I diamati oleh 2 observer yakni guru mata pelajaran sebagai observer 1 dan teman sejawat sebagai observer 2. Pada tindakan I perolehan skor dari hasil pengamatan berturut-turut adalah sebesar 79 dan 81, dengan skor maksimal sebesar 100. Hasil observasi aktivitas guru pada tindakan siklus I dapat dilihat pada Tabel 2 berikut ini.

Tabel 2. hasil observasi aktivitas guru

\begin{tabular}{cccc}
\hline & Skor yang diperoleh & Persentase & Kriteria \\
\hline Observer 1 & 79 & $79 \%$ & Baik \\
Observer 2 & 81 & $81 \%$ & Baik \\
\hline Rata-rata & & $80 \%$ & Baik \\
\hline
\end{tabular}

Observasi kegiatan peserta didik pada tindakan siklus I juga diamati oleh 2 observer yakni guru mata pelajaran dan teman sejawat yang masing-masing berperan sebagai observer 1 dan observer 2. Pada tindakan I perolehan skor dari hasil pengamatan berturut-turut adalah sebesar 63 dan 65, dengan skor maksimal sebesar 92. Hasil observasi aktivitas guru pada tindakan siklus I dapat dilihat pada Tabel 3 berikut ini.

Tabel 3. hasil observasi aktivitas peserta didik

\begin{tabular}{cccc}
\hline & Skor yang diperoleh & Persentase & Kriteria \\
\hline Observer 1 & 65 & $70,65 \%$ & Baik \\
Observer 2 & 67 & $72,82 \%$ & Baik \\
\hline Rata-rata & & $71,73 \%$ & Baik \\
\hline
\end{tabular}

Selama pembelajaran pada tindakan siklus I terdapat berbagai kendala yang ditemui oleh peneliti. Kendala tersebut adalah sebagai berikut:

1. Selama pembelajaran berlangsung masih ada peserta didik yang ramai sehingga suasana kelas menjadi kurang kondusif.

2. Pada saat penyajian materi, peneliti kadang menjelaskan materi terlalu cepat dan pemberian contoh soal masih kurang.

3. Ada beberapa peserta didik yang masih belum memahami materi mengenai penyelesaian SPLDV.

4. Masih ada peserta didik yang tidak menerima pembagian kelompok sehingga menyebabkan kegaduhan di kelas. 
5. Pada saat pembelajaran talking stick berlangsung, ada peserta didik yang tidak memberikan tongkat secara estafet sehingga menyebabkan proses pembelajaran menjadi terhambat.

Ditinjau dari kendala yang diperoleh peneliti pada tindakan siklus I, maka peneliti membuat perbaikan pada siklus II yakni, peneliti lebih mengkondisikan suasana kelas, menjelaskan materi sesuai data dan waktu yang telah ditentukan dan memberikan contoh soal yang lebih banyak, memberikan materi substitusi sebagai materi apersepsi, memberikan penegasan sangsi apabila masih ada peserta didik yang tidak menerima kelompok yang dibagikan, dan memberikan sanksi yang tegas apabila masih ada peserta didik yang memberikan tongkat dengan cara melempar seperti meminta peserta didik tersebut untuk menjawab soal.

Dari hasil tes pada tindakan siklus II yang dilakukan diperoleh dari 32 peserta didik terdapat 26 peserta didik tuntas dalam belajar dengan nilai $\geq 75$ dan 6 peserta didik dinyatakan tidak tuntas belajar karena memperoleh nilai di bawah KKM. Dengan demikian dapat dihitung persentase ketuntasan hasil belajar peserta didik secara klasikal adalah 81,25\%. Dari persentase tersebut, dapat diketahui bahwa persentase ketuntasan belajar sudah mencapai standar ketuntasan belajar.

Pada tindakan siklus II, skor hasil observasi aktivitas guru yang diamati oleh guru mata pelajaran dan teman sejawat berturut-turut adalah sebesar 88 dan 91, dengan skor maksimal 100. Guru mata pelajaran dan teman sejawat masing-masing berperan sebagai observer 1 dan observer 2. Hasil observasi aktivitas guru pada tindakan siklus I disajikan pada Tabel 4 berikut.

Tabel 4. hasil observasi aktivitas guru

\begin{tabular}{cccc}
\hline & Skor yang diperoleh & Persentase & Kriteria \\
\hline Observer 1 & 88 & $88 \%$ & Sangat Baik \\
Observer 2 & 91 & $91 \%$ & Sangat Baik \\
\hline Rata-rata & & $89,5 \%$ & Sangat Baik \\
\hline
\end{tabular}

Skor hasil observasi aktivitas peserta didik oleh masing-masing observer adalah 75 dan 78, dengan skor maksimal 92. Hasil observasi aktivitas peserta didik pada tindakan siklus II dapat dilihat pada Tabel 5 berikut.

Tabel 5. hasil observasi aktivitas peserta didik

\begin{tabular}{cccc} 
& Skor yang diperoleh & Persentase & \multirow{2}{*}{ Kriteria } \\
\hline Observer 1 & 75 & $81,52 \%$ & Baik \\
Observer 2 & 78 & $84,78 \%$ & Baik \\
\hline Rata-rata & $83,15 \%$ & Baik \\
\hline \multicolumn{4}{c}{ Tabel 6. hasil tes peserta didik } \\
\hline \multicolumn{4}{c}{ Persentase } \\
\hline Pumlah Peserta Didik & Kriteria \\
Pra Siklus & Tuntas & $56,25 \%$ & Tidak Berhasil \\
Siklus I & 14 & $65,62 \%$ & Tidak Berhasil \\
& 21 & $81,25 \%$ & Berhasil \\
\hline
\end{tabular}

Penerapan pembelajaran kooperatif tipe talking stick berbantuan dadu dan microsoft power point meliputi tiga tahap yaitu, kegiatan awal, kegiatan inti dan kegiatan akhir. Pada kegiatan awal, peneliti menyampaikan tujuan pembelajaran yang akan dilakukan, serta memberikan apersepsi tentang materi sebelumnya. Tujuan pembelajaran sangat penting diinformasikan kepada peserta didik karena pada dasarnya merupakan target yang akan dicapai dari pembelajaran yang dilakukan. Emda (2017:179) menyampaikan bahwa tujuan yang jelas dapat menumbuhkan minat belajar peserta didik, semakin jelas tujuan yang ingin dicapai, maka akan semakin kuat minat belajar peserta didik. 
Pada kegiatan ini, peneliti menyampaikan materi yang berkaitan dengan sistem persamaan linear dua variabel. Pada saat memberikan penjelasan, peneliti memberikan contohcontoh soal yang disertakan dengan penyelesaiannya. Pemberian contoh dimaksudkan agar peserta didik lebih mudah memahami materi dan dapat mengerjakan soal yang telah disiapkan oleh peneliti.

Selanjutnya peneliti menginstrusikan kepada peserta didik untuk berkumpul bersama kelompok yang telah dibagikan secara heterogen. Pada saat pembagian kelompok siklus I, terdapat beberapa peserta didik yang tidak terima dan puas dengan kelompok yang dibagi oleh peneliti sehingga pada saat model pembelaran talking stick berlangsung terlihat bahwa mereka tidak aktif dalam kelompok. Pada siklus II, peneliti membuat daftar pembagian kelompok sesuai hasil tes siklus I dan selanjutnya mendiskusikan dengan guru mata pelajaran matematika karena guru matematika lebih memahami karakteristik peserta didik. Oleh karenanya, pembagian kelompok dilakukan berdasarkan karakteristik peserta didik. Hal ini sesuai dengan pendapat Slavin (2010:4) yang mengatakan bahwa kelompok heterogen dan berdasarkan karakteristik peserta didik diharapkan pembelajaran lebih efektif, peserta didik dapat saling bekerja sama, berdiskusi, dan berargumentasi untuk mengasah kemampuan yang dimiliki dan menutup kesenjangan dalam pemahaman masing-masing peserta didik.

Selanjutnya, peneliti melaksanakan talking stick berbantuan dadu dan microsoft power point. Peneliti mengatur tempat duduk peserta didik sesuai kelompok dan menjelaskan aturan talking stick. Pada pembelajaran talking stick peserta didik lebih tertarik dan senang mengikuti pembelajaran. Pada penelitian ini, peneliti menggunakan media pembelajaran berbasis multimedia yang dapat membantu pembelajaran talking stick yakni media power point. Power point ini akan menampilkan materi yang akan dijelaskan oleh peneliti termasuk soal-soal yang akan digunakan selama pembelajaran talking stick berlangsung. Materi dan soal yang disampaikan, disajikan dengan menarik dan bervariasi sehingga dapat memfokuskan perhatian peserta didik untuk mendengarkan penjelasan guru. Penyampaian materi dan soal menggunakan media power point bertujuan untuk membantu peserta didik agar lebih mudah mengingat materi yang disampaikan. Kusuma (2013:2) mengatakan bahwa media pembelajaran memiliki beberapa manfaat, diantaranya menghilangkan stres, mengajak peserta didik terlibat penuh dalam pembelajaran, dan membangun kegiatan belajar yang menyenangkan.

Pada saat siklus I, selama pembelajaran talking stick berlangsung, masih banyak peserta didik yang ramai dan melempar tongkat yang digunakan selama pembelajaran. Hal ini menghambat jalannya pembelajaran dan membuat banyak waktu yang terbuang. Pada siklus II, peneliti memberikan sangsi yang tegas kepada peserta didik yang masih melempar tongkat dan ramai, hal ini sesuai dengan pendapat Sardiman (2011) yang menyatakan bahwa hukuman yang diberikan secara tepat dapat menjadi alat motivasi bagi peserta didik.

Bersamaan dengan kegiatan talking stick berbantuan dadu dan microsoft power point, peneliti memberikan penghargaan atau hadiah kepada kelompok yang mendapat skor tertinggi. Peserta didik terlihat bersemangat dan aktif setelah mendapatkan hadiah dari peneliti. Hal ini sesuai dengan pendapat Sagala (2014:43) yang menyatakan bahwa pemberian penghargaan akan membuat peserta didik belajar lebih rajin dan bersemangat.

Pada kegiatan akhir, peserta didik dibantu oleh peneliti melakukan refleksi dan evaluasi terhadap pembelajaran yang telah dilakukan. Kegiatan ini dilakukan untuk mempertahankan daya ingat peserta didik terhadap materi yang telah dipelajari.

Pertemuan berikutnya, peneliti menyampaikan kegiatan yang akan dilakukan yakni tes akhir siklus. Sebelum memulai tes akhir siklus, peneliti melakukan tanya jawab untuk mengingatkan materi yang dipelajari pada pertemuan sebelumnya.

Kegiatan pembelajaran diakhiri dengan pelaksanaan tes akhir siklus. Tes ini dilakukan untuk mengetahui pemahaman peserta didik terhadap materi yang telah dipelajari. Hal ini sesuai dengan pendapat Sudjana (2009) yang menyatakan bahwa penilaian berfungsi untuk mengetahui tercapai tidaknya tujuan pengajaran, dengan fungsi ini dapat diketahui tingkat penguasaan bahan pelajaran atau dengan kata lain dapat diketahui hasil belajar yang dicapai oleh peserta didik. Di akhir pembelajaran, peneliti menutup dengan mengucapkan salam. 


\section{PENUTUP}

Berdasarkan paparan data dan temuan penelitian yang dijabarkan, maka kesimpulan yang dapat diambil adalah sebagai berikut, (1) Guru membuka pelajaran kemudian menyampaikan tujuan pembelajaran yang akan dilakukan dan memberikan apersepsi tentang materi sebelumnya. Selanjutnya guru memberikan motivasi kepada peserta didik tentang manfaat mempelajari materi sistem persamaan linear dua variabel, (2) Guru menjelaskan secara rinci dan jelas materi yang diajarkan yakni penyelesaian sistem persamaan linear dua variabel (SPLDV). Pada tahap ini, guru memberikan banyak contoh soal dengan pertimbangan pada siklus I masih banyak peserta didik yang belum menguasai materi. Penyajian materi diberikan melalui bantuan power point yang telah disediakan, (3) guru membagi peserta didik ke dalam 5 kelompok beranggotakan 6 peserta didik secara heterogen, (4) Guru menyerahkan nomor dada yang akan dipakai oleh peserta didik pada tiap kelompok, (5) Guru menyiapkan tongkat dan dadu, setelah itu guru memberikan tongkat kepada salah satu kelompok dan mulai memainkan musik, peserta didik memberikan tongkat secara estafet dari satu kelompok ke kelompok yang lain, (6) Guru melempar dadu dan mengundi peserta didik mana yang harus menjawab soal dan nomor soal yang akan dikerjakan oleh kelompok tersebut menggunakan dadu yang telah disediakan, (7) Peserta didik mengerjakan soal di papan, (8) Guru memberikan penghargaan kepada kelompok yang memperoleh skor tertinggi, dan (9) Guru bersama peserta didik melakukan refleksi dan evalusi untuk membuat kesimpulan dari pembelajaran yang telah dilakukan. Guru memberikan tes secara individu bertujuan untuk mengetahui pemahaman peserta didik tentang materi yang telah diajarkan.

Peningkatan persentase ketuntasan peserta didik secara klasikal pada tahap pra tindakan sebesar 56,25\%, menjadi $65,62 \%$ pada tes akhir siklus I, dan $81,25 \%$ pada tes akhir siklus II. Peserta didik yang telah memenuhi kriteria ketuntasan minimal (KKM) yang ditetapkan sekolah adalah 18 peserta didik pada tahap pra tindakan, menjadi 21 peserta didik pada siklus I dan 26 peserta didik pada siklus II. Sehingga dapat disimpulkan bahwa model pembelajaran talking stick berbantuan dadu dan microsoft power point dapat meningkatkan hasil belajar peserta didik.

Berdasarkan kesimpulan penelitian tindakan di kelas VIII B SMP PGRI 6 Malang, ada beberapa saran yang perlu disampaikan yakni: (1) Sebaiknya guru menyediakan waktu yang cukup untuk talking stick agar sebagian peserta didik dalam kelompok mendapat giliran untuk menjawab soal, dan guru juga mempertimbangkan materi yang cocok untuk pembelajaran talking stick berbantuan dadu dan microsoft power point, (2) Guru matematika yang ingin melakukan model pembelajaran kooperatif tipe talking stick berbantuan dadu dan microsoft power point, sebaiknya menyediakan media power point dengan lebih menarik, jika tidak ingin menggunakan power point maka guru bisa menyiapkan Lembar Kerja Kelompok untuk mempermudah peserta didik mengerjakan soal.

\section{DAFTAR PUSTAKA}

Afifah, D. S. 2012. Interaksi Belajar Matematika Siswa Dalam Pembelajaran Kooperatif Tipe STAD. Jurnal Pegagogia, 1(2): 145-151.

Crismono, P. C. 2017. Pengaruh Outdoor Learning Terhadap Kemampuan Berpikir Kritis Matematis Siswa. Jurnal Pendidikan Matematika dan Sains , 4 (2): 106113.

Emda, A. 2017. Kedudukan Motivasi Belajar Siswa dalam Pembelajaran. Lantanida Journal, 5(2): 172-182.

Hanisah, Siti, S Tri and B Setyo. 2014. Penggunaan Model Pembelajaran Kooperatif Tipe Team Group Investigation Dalam Peningkatan Pembelajran Matematika Tentang Pecahan Pada Kelas V SD. Kalam Cendekia, 2(2): 1-7.

Kurniati, I. 2017. Model Pembelajaran Discovery Learning Berbantuan Smart Sticker untukMeningkatkan Disposisi Matematika dan Kemampuan Berpikir Kritis. Jurnal Matematika Kreatif-Inovatif, 8(2):109-118. 
Kusuma, A. I. 2013. Pengembangan Media Pembelajaran melalui Permainan "Hunting Treasure" pada Materi Himpunan untuk Siswa Kelas Bilingual VII-A di SMP Negeri 16 Malang. Jurnal Online, 1(2): 1-7.

Malisa, P. I. 2014. Penerapan Model Talking Stick Dalam Pembelajaran Matematika Siswa Kelas VI SMP Negeri 2 Sangalla'. Jurnal Keguruan dan Ilmu Pendidikan, 3(2): 533-536.

Minu, M., Hariyani, Sri., Rahaju. 2018. Penerapan Model Pembelajaran Talking Stick Untuk Meningkatkan Hasil Belajar Materi Statistika Siswa SMP. Seminar Nasional FST 2018 Universitas Kanjuruhan Malang, 1: 651-661

Mustamid, H. 2015. Pengaruh Efektivitas Multimedia Pembelajaran Makromedia Flash 8 Terhadap Motivasi Belajar Siswa Pada Materi Fungsi Komposisi dan Invers. Jurnal EduMa, 4(1): 26-42.

Novida, I. 2016. Penerapan Model Talking Stick Untuk Meningkatkan Hasil Belajar IPS Pada Materi Jasa dan Peranan Tokoh Pejuang Dalam Memproklamasikan Kemerdekaan Indonesia Pada Siswa Kelas V SD Negeri 20 Meulaboh Kabupaten Aceh Barat. Jurnal Bina Gogik, 1(3): 1-14.

Puspitawangi, K. R., Wibawa, I M. C., Pudjawan, K. 2016. Pengaruh Model Pembelajaran Kooperatif Tipe Talking Stick Berbantuan Media Audio Terhadap Hasil Belajar IPS Siswa. Jurnal PGSD, 1(4): 1-12.

Putri, A. I. K., Trihandono, T., Putra, P. D. A. 2017. Penerapan Model Pembelajaran Talking Stcik Disertai Metode Demonstrasi Berbantuan Media KOKAMI Mata Pelajaran IPA di SMP. Jurnal Pembelajaran Fisika, 4(5): 321-328.

Sagala, S. 2010. Konsep Pembelajaran untuk Membantu Memecahkan Problematika Belajar dan Mengajar. Bandung: Alfabeta.

Sardiman, A. M. 2011. Interaksi \& Motivasi Belajar. Jakarta: Rajagafindo Persada.

Slavin, R. 2010. Cooperative Learning. Bandung: Nusa Media.

Sudjana, N. 2009. Penilaian Hasil Proses Belajar Mengajar. Bandung; Remaja Rosdakarya.

Susiliana, R. Dan Riyana, C. 2009. Media Pembelajaran: Hakikat, Pengembangan, Pemanfaatan dan Penilaian. Bandung: CV Wacana Prima.

Sutrisno, D \& Retnawati, H. 2015. Komparasi Pendekatan Penemuan Terbimbing dalam Pembelajaran Kooperatif. Jurnal Pendidikan Matematika, 10(1): 15-27. 